\title{
Quick Money and Power: Tomatoes and Livelihood Building in Rural Brong Ahafo, Ghana*
}

\author{
Christine Okali and James Sumberg
}

Abstract This article uses the example of small-scale, labour-intensive tomato production in Brong Ahafo, Ghana to explore some prospects of young people's engagement with the agri-food sector in Africa. Although tomatoes were produced by men and women of all ages, a significant proportion of young men specialised entirely in tomato production, growing three crops per year. Tomato production met short-term capital needs for home-building, marriage, business development and adventure. Young women also engaged in tomato production, although rarely as ' 3 -croppers'. A return visit examined the role agriculture played in enabling young people to achieve their earlier life and work objectives. A social-relational approach was adopted, focusing on interdependency and linked lives. Life course analysis highlights shifts that have implications for the changing way people engage in agriculture, rather than assuming that 'one size fits all at all times'.

\begin{abstract}
1 Introduction
There is real tension among the common policy narratives around 'youth' in Africa. On the one hand young people are portrayed as a valuable resource - 'the future of the nation', while on the other they are described as unemployed and underemployed, work-shy, vulnerable, undisciplined and prone to risky and antisocial behaviour (Anyidoho et al. 2012). In addition, in most youth-related policies and the narratives that support them, 'youth' are presented as a homogeneous group, undifferentiated by gender, age, class or religion, and existing independently of families, communities and broader social relations.
\end{abstract}

In this article we argue that a similar and related tension can be shown to exist between how rural young women and men actually engage with and use agriculture to build their livelihoods, and the policies and programmes commonly relied upon to address the 'youth in agriculture' problem. Based on a case study of young tomato growers in Brong Ahafo, Ghana, we argue that unless and until policy moves beyond this 'Jekyll and Hyde' portrayal of young people, and begins to appreciate them as part of the rest of society, yet seeking their independence, it is unlikely to contribute either to the wellbeing of the young people themselves or to the development of the agricultural sector. In policy terms, this also means that when strategising around the wellbeing of rural young people it is not reasonable to start with agriculture. Neither is it reasonable, when strategising around agricultural development, to start with the 'youth problem'.

'Youth' have vexed agriculture and rural development policymakers in Africa for a very long time. Indeed, the image of a mass migration of young men from rural areas has been used to justify numerous programmes aimed at keeping them in rural areas and engaged in agriculture. These programmes historically centred on providing young, possibly married, men with a farming package that addressed the less glamorous aspects of small-scale agriculture hard labour with hand tools. One well-documented example is the Ilora Farm Settlement Scheme, initiated in Nigeria's former Western State in 1959 (Spiro 1985). This scheme was one of a number initiated in various parts of the state to:

- attract educated young people into viable farming units as an alternative to urban living; 
- demonstrate that carefully planned farming systems can be satisfying and lucrative;

- raise agricultural production to supply the growing population of the country as well as to maintain exportable products.

'Progressive farmers', 'scientific farming', 'mechanisation' and 'reduced drudgery', along with a 'superior way of life', were all referred to in the early documentation. The description of the Ilora Settlement reads like a novel, with young married couples happily settling into their new dream homes and work environment. It is not a picture of young men and women, together and/or separately building their independent lives, possibly but not necessarily remaining in their places of origin and using agriculture as a means to achieve this independence.

Although the scheme objectives did not explicitly exclude young women, by omission and by later reference to 'settler wives', women were envisaged as working for and under their husbands. Indeed, the farm plans relied on their labour, which left 14 of the original settlers who were not married, in a difficult position. Equally, while cooperative membership was automatic for all male settlers, wives (at least initially no women were allocated land in their own right) were not automatically given membership.

These schemes soon experienced problems of settler turnover, and even desertion. Between 1960 and 1965, 42 per cent of the original settlers had left, citing low incomes, hard work and poor-quality houses. Few settlers were able to plant all their allocated land (25 acres for arable crops and 25 acres for fallow plus cages for broilers) because of insufficient labour, and by the 1980s, a number of farms had been merged to form large-scale units devoted to maize production. In respect of labour, no facilities had been made available for visitors or other family members to join settlers at times of peak labour demand. Wives were among the first to leave the settlement: they were not supported in their agricultural or trading interests, or in meeting their domestic obligations; they did not have access to modern equipment to reduce the burden of food processing and preparation, fuel or water provisioning. By 1976, 30 per cent of wives in the remaining households had decided to live elsewhere. While the 1976 report suggests that settlement wives had gained in some respects relative to their counterparts in surrounding villages (e.g. they contributed much smaller shares of their small maize and cassava plots to household requirements than their spouses), these advantages were apparently insufficient to keep them on the site. Their departure was also supported by local Yoruba culture that encouraged husbands and wives to accumulate independent means to meet their joint and separate obligations at household and wider levels, and by 1976 the downward spiral of the scheme as a living settlement was continuing with men living in nearby towns and visiting the settlement only when necessary (Spiro 1985).

In conception, the Ilora Farm Settlement is not a million miles away from the Block Farm Programme that is today the central pillar of the Youth in Agriculture Programme at Ghana's Ministry of Food and Agriculture (Benin et al. 2012). The Block Farm Programme seeks to:

- generate employment among the rural poor, especially the youth (emphasis added);

- improve incomes among farmers by at least 50 per cent;

- increase food security through the use of science and technology leading to increased productivity and higher yields;

- improve farming as a business.

Unlike the Ilora Scheme, Block Farms do not involve resettlement. However, despite being separated by 50 years of development experience, with their common focus on youth, better organisation, increased scale and the use of new technology and mechanisation to improve productivity and profitability, they have much in common.

Here we use the example of young tomato growers to argue that Block Farms and other related approaches do not appear to reflect either the diversity or the dynamics of young people's actual - indeed instrumental - use of agriculture to build their livelihoods. Specifically, we demonstrate that young people use particular forms of engagement in agriculture to meet tightly circumscribed, age-related livelihood needs such as building a house, starting a business, getting married, starting a family and seeking adventure. Further, some investment, made possible through successful tomato production, is geared largely towards exiting 
from agriculture. While these investments may not always yield the desired results and agriculture may remain a part of livelihood portfolios, we suggest that this instrumental use of agriculture has important policy-relevant implications for thinking about livelihoods and sustainability within a thriving agricultural economy. For example, programmes such as Block Farms are built on the assumption that they can provide the basis for young people to establish a career in agriculture. However, it is not at all clear either that young people's engagement in agriculture is constrained by the factors addressed by the Block Farm Programme, or that they are even interested in careers dominated by farming.

The remainder of the article is in four parts. In the next section we introduce the case study village - Pamdu - and its small-scale commercial tomato producers. Following this, we turn to the various ways that male and female tomato producers gain access to key resources. Here we demonstrate that while access to resources including land, labour, capital, and food is a prerequisite for accumulation via tomato production, there are alternative ways in which these resources can be accessed. This means that while different young people - men and women, indigenes and 'strangers', those from

landholding families and those not - can engage in tomato production, the type and scale of their engagement, and thus ability to accumulate surplus, is both enabled and to some degree circumscribed by their social relations and networks. Next, we focus on life and work expectations and achievements, and the role that tomato production played in these. The article concludes with some suggestions as to the relevance of these findings for policy relating to what is frequently described as the 'youth in agriculture' problem.

The article is based on an initial visit to Pamdu in 1995 and a more extensive period of fieldwork undertaken between January and April 1999. Data collection included a village census designed to locate tomato producers and provide some detail about farming activities in general, a questionnaire administered to 73 tomato producers, interviews with key informants, and group discussions. Key informants helped us to piece together the historical, institutional, and social contexts in which commercial tomato production had developed at this and neighbouring sites. ${ }^{1}$ Using a sample of 27 of the tomato producers interviewed in 1999, a four-day restudy was undertaken in September 2011 to follow up on how they had actually used returns from commercial tomato production, and where agriculture fits into their lives today.

\section{Pamdu village}

Pamdu village is located in Brong Ahafo Region (Nkoranza Traditional Area, Kintampo District) on the main tarmac road between Techiman $(32 \mathrm{~km}$ to the south) and Kintampo $(27 \mathrm{~km}$ to the north). Its location between these two commercial centres places it in an ideal position for accessing food markets both to the north and south. Equally, its geographical position at the interface between the tree-based, forest farming systems to the south and savannah systems to the north makes it an ideal location for growing a wide range of food crops including maize, yams, cassava, cowpea, tomato, garden egg, okra, carrots, cabbage and pepper, as well as tree crops, especially cashew, mango and palm, and plantain. All of these are marketed to a greater or lesser extent, but yam and cassava are produced largely for people's own consumption. In most years two crops of maize and/or cowpea can be grown. From the late 1970s and early 1980s tomato cultivation developed as a major enterprise in Pamdu and surrounding villages. By the late 1990s, tomatoes were grown to a greater or lesser degree by men and women of all ages. As such, tomato production was making a critical contribution to both individual incomes, and to the village economy at the time of our fieldwork in January 1999, when 77 per cent of households reported at least one person growing tomatoes commercially. By the time of our second visit a decade later, the tomato economy was less active, largely, as reported by residents, because the market had shifted substantially in favour of production from further north (i.e. Burkina Faso).

During the rainy season two crops of tomatoes can be grown on upland fields. Dry season tomatoes, referred to as petera, are grown only in close proximity to the River Dum and its small tributaries because they must be irrigated twice daily, and most irrigation water is carried by hand (in 1999 only two or three farmers used pumped irrigation water and this number had not increased by 2011). Tomato production is dependent on significant inputs of fertiliser and 
pesticide. In 1999 there were a small number of formal channels for consultation and collective action around farming and natural resource management, including the Pamdu Tomato Farmers Association, the Aworate Multi-Purpose Cooperative, and the Cashew Farmers Association (Sumberg and Okali 2006).

In January 1999 the total population of Pamdu village was 935 . The majority of the population were Akan who also comprise approximately 45 per cent of the population of Ghana, and occupy most of the southern half of the country. Pamdu is situated in a zone that has over many years attracted long-term migrants from the northern regions of Ghana in search of farming opportunities, as well as short-term immigrants for farm labouring. It was northerners that in January 1999 dominated the village's non-Akan adult population ('strangers').

The economy of these strangers was distinctly different from that of the Akan - their agricultural interests were centred on their customary crops of yam, cowpeas and maize, with the occasional field of guinea corn (sorghum) grown for beer-making. In contrast to their Akan neighbours, only in a small proportion of northern households were there individuals engaged directly in tomato production. While many of the non-Akan residents had been in the village for many years, like their Akan neighbours, they retained links with their home areas and there was frequent movement of women and men between Pamdu and places of origin. Even those we refer to as 'resident Akan' originated from elsewhere and retained strong links with these areas. Thus, in a number of respects Pamdu resembles a pioneer camp, with a large proportion of small households comprised of spouses, and much new building in evidence. Although the contrast between Akan and nonAkan residents is not pursued in great detail in this article, it serves to demonstrate the complexity and diversity of the rural social settings in this part of West Africa.

\subsection{Small-scale commercial tomato producers}

In the late 1990s intensive, market-oriented tomato production was one of the few widely accessible, land-based activities in this area offering significant financial returns in the short term, and it was therefore particularly important in the livelihood building and accumulation strategies of young men and women (Okali and Sumberg 1999).

In January 1999, 58 per cent of adult residents of Pamdu over 15 years of age were reported to have grown at least one commercial vegetable crop in the preceding 12 months, and 73 per cent of these grew tomatoes. Overall, 57 per cent of men and 27 per cent of women grew tomatoes but more significantly, of the 129 residential buildings in the village, only 23 per cent did not have at least one resident tomato producer (while 21 per cent had three or more tomato producers). Engagement in tomato production was not, however, uniformly distributed among the population: while 88 per cent of Akan households had at least one tomato producer, only 48 per cent of 'other' households were in this position. Similarly, Akan men were more than twice as likely to grow at least one tomato crop than men of other groups (68 per cent compared with 32 per cent), while the percentage of Akan women growing tomatoes was four times higher than that of 'other' women.

In 1999 we distinguished between two basic patterns of engagement in tomato production. In a given year the vast majority of producers either grew only during the rainy season (1- or 2-croppers), or they grew three crops, two during the rainy season plus an irrigated crop during the dry season (3-croppers). Women were less engaged in tomato production than men, and were planting smaller areas than men: only 12 per cent of female producers were classed as 3 -croppers (compared with 45 per cent of male producers), and female 3 -croppers were more likely to be older women: Akan women in the $36-45$ age category were the most active producers with up to 45 per cent of this age category engaged in tomato production. A number of women had only recently started tomato production, and five reported starting production the previous year using a loan from a development organisation with a local programme in Pamdu, the 'Freedom of the Queens' (FREQUE). ${ }^{2}$ In general, because of their small tomato plots, women were more likely to report their production in terms of rubber buckets rather than crates, ${ }^{3}$ and for some, their production was either so small or so dispersed over time that they had little conception of the total quantities involved. In addition, their patterns of engagement in tomato 
production appeared to be considerably more fragmented that those of men. Women were also more active in producing vegetable crops other than tomatoes. Having said this, there were four women, each related to a prominent man, engaged in tomato production on a scale equivalent to that of the larger male producers. ${ }^{4}$

Based on our comparisons of engagement in tomato production across sex and age groups, we could observe how patterns of tomato production change over the life cycle. Many young, single men devoted most of their farming and work energies to tomato production: staple food crops such as yams or maize received little of their attention. With marriage, in general, tomatoes became relatively less important. Thus, while men in the 26-35 age category farmed on average 0.6 acres (0.24ha) of tomatoes, more than those in the 16-25 category, the area of tomatoes as a proportion of that sown to maize and yam decreased from 70 per cent for those aged 16-25, to 28 per cent for those over 35 years of age. The proportion of men producing tomatoes during the dry season also declined with increasing age. Older female tomato growers were also more likely to grow both maize and yam. However, in contrast to the men, with increasing age they devoted a larger area to tomato relative to maize and yam.

Although the proportion of women reporting an active engagement in tomato production was comparatively small, the majority (72 per cent) of female tomato producers, but especially younger, unmarried and more educated women, also reported having some off-farm income. They farmed a smaller area of land and reported producing on average 29 per cent fewer crates of tomatoes (during the previous year) than those without off-farm income. It is important to note that those with off-farm income were not investing this in tomato production. This was very different from their male counterparts of whom only 46 per cent reported off-farm incomes, and this income was apparently used to expand their farming activities. Their tomato plots were larger and production per acre greater than those who only farmed.

In the next section we address the variation in agricultural activities by different age, sex and ethnic groups by examining the access to the key resources required for the intensive production of tomatoes.

\section{Access to key inputs and resources}

The ability to engage in agricultural activities that are expected to lead to rapid and significant capital accumulation depends, at a minimum, on timely access to sufficient quantities of land, labour, capital, markets and information, and explanations of differences in levels of engagement in agriculture between different categories of producers have frequently focused on access to these resources. Both the Ghana Block Farm programme and especially the Nigerian Farm Settlement policies were designed in a context where access to these resources was assumed to constrain young people's farming activities. Literature on women in agriculture would lead us to hypothesise that disadvantage in terms of resource access will explain the more limited engagement of young Pamdu women in tomato production, and especially dry season production (Okali 2012). Given customary landholding arrangements, we might also hypothesise that the involvement of non-Akan residents in tomato production would be similarly constrained.

These issues around resource access are examined below. Here we focus especially on access to land, labour and capital. In addition we consider access to food for consumption, both in acknowledgement of the time needed to prepare food, and the understanding that making food available on a daily basis constrains both women's independent farming activities, even before marriage, and the crop choice of young men as they marry and take on domestic responsibilities.

\subsection{Land}

In customary (Akan) practice, land is accessed through chiefs and families. The land associated with Pamdu village is for all intents and purposes controlled by seven families - localised segments of matrilineages (Okali 1983) - each having different land endowments in terms of both quantity and quality (i.e. upland or riverside land). The majority of Akan residents can trace links (either through birth, adoption or marriage) with one, if not more of these seven landholding families. However, having links to one of these families does not in itself guarantee access to any land, much less to a sufficient quantity of land of a specific type. Rather, individuals, whether or not they are from landowning families, gain access to land through a variety of other 


\begin{tabular}{|c|c|c|c|c|}
\hline & \multicolumn{4}{|c|}{ Tomato production season } \\
\hline & Wet & & Dry & \\
\hline Access & Male & Female & Male & Female \\
\hline Usufruct via father's or mother's family & 44.9 & 34.8 & 42.3 & 16.7 \\
\hline Rented & 36.0 & 23.9 & 50.0 & 83.3 \\
\hline Via spouse or borrowed & 5.6 & 41.3 & 3.8 & 0 \\
\hline Own & 13.5 & 0 & 3.8 & 0 \\
\hline All & $100(N=89)$ & $100(N=46)$ & $100(\mathrm{~N}=26)$ & $100(\mathrm{~N}=6)$ \\
\hline
\end{tabular}

arrangements including short- and long-term rental, and increasingly today, land sales (Kipo Jimah pers. comm. 2011; Berry 2009; Amanor 2010). Residents of Pamdu, whether they are members of landholding families, belong to other local families, or are temporary or long-term migrants from other parts of the country, use all their connections, including those of birth, lineage, marriage, friendship, and the market, to gain access to land.

To what extent were different individuals more or less reliant on family ties for the land on which they grew tomatoes and other crops? Over all crops and seasons within a 12-month period (i.e. covering 434 individual plots), the two most common means of gaining access to land were via the father's or mother's family (40.5 per cent), and renting (33.8 per cent). Together these accounted for 75 per cent of plots. During the rainy season the means of access to tomato and non-tomato plots were broadly similar, while nearly twice as many dry season tomato plots were rented and fewer were 'own' plots or accessed via spouse or gift (Table 1). Therefore, individuals whose father came from Pamdu were more likely to report farming their own land, but also to having gained access to a substantial proportion of the land they farm via their fathers. On the other hand, for individuals whose mother was from Pamdu, this link (via the mother's family) was particularly important for access to land. As we might have expected, for individuals with neither parent from Pamdu, renting was the single most important means of gaining access to land (55 per cent of plots). Non-Akan dry season producers rented 87 per cent of their plots.
What were the dominant patterns among the Akan female producers? Compared to men, a higher proportion of Akan women tomato producers reported that neither parent was from Pamdu, and the women involved in dry season production were more likely to be renting their plots than men: 50 per cent of men's and 83 per cent of women's dry season plots were rented.

These data show that individuals, whether men or women, young or old, with or without local family ties, use a variety of channels to access land for tomato production. For some, family ties were certainly important. Nevertheless, there was no indication whatsoever that access to land was restricted for those without such family ties, In fact, individuals without any family links to Pamdu were among those with the largest farmed areas (and nearly 90 per cent of this land was rented), and the most common response to a question about the availability of additional land was along the lines of 'If I have the money I can get more land'.

\subsection{Labour}

Discussions around the topic of labour and tomato production centred on the arduous nature of the work, particularly during the dry season; the advantages that accrue to young men who were willing and able to exploit their own labour ('quick money'); and the important role played by hired labour in preparation of yam mounds, maize sowing and weeding, 'earthing$\mathrm{up}^{5}$ and harvesting of wet season tomatoes. While men and women reported assisting one another in a variety of farming activities and while older men might have greater access to 'family labour' for farming, no one regarded 
these arrangements as indicating 'joint production'. Respondents were at pains to make it clear that the production of tomatoes and other vegetables was an individual activity, 'because that is a cash crop'. No one complained of being unable to hire labour when it was needed although labourers might give priority to some farmers during the season of peak labour demand. Although it was men from the north who were most likely to work as hired labour on fields, many other individuals, both men and women, reported that they would hire out their own labour when they needed cash.

In terms of tomato production, those who were willing and able to exploit their own labour appeared to have the greatest advantage, and in general, it was young men who were in this position. In contrast to older men, however, the young, unmarried men could not formally call on or control the labour of others such as family members, although a few reported occasionally seeking assistance from their sisters and mothers. This may explain why it was among young men that nnoboa (cooperative labour groups $)^{6}$ appeared to be of most interest. In general, young women did not see themselves as being able to meet the labour demand associated with tomato production, and concentrated on other vegetable crops such as okra and pepper that were less management- and labourintensive. Overall, however, the most advantaged producers in terms of labour appeared to be those with the income to hire labour. At least one male teacher relied totally on hired labour for his dry season production, and he attributed his good yields to his ability to hire labour when he needed it.

\subsection{Capital and credit}

The two main physical inputs used in tomato production in Pamdu are inorganic fertiliser and pesticides. Both could be purchased from the agro-chemicals kiosk in the village but were also available from shops in the nearby towns of Kintampo and Techiman. The owner of the agrochemicals kiosk, a local man, was without question an important source of operational credit for a large number of male and female tomato producers. At the beginning of the 1998/9 dry season, for example, his records showed outstanding debts valued at Ghana cedi 1.2 million $^{7}$ from approximately 150 people, including 28 women. Nevertheless, while women were on record as having obtained credit for the purchase of inputs, female respondents more frequently reported that they relied on their spouse or close relatives for their agro-chemical supplies.

Access to operating capital is essential for successful tomato production as cash is needed both to purchase fertiliser and pesticides, and to pay labour prior to harvest. During the dry season even land rent must be paid in advance. Depending on the season and the use of hired labour, operating capital requirements for a single crop of tomatoes might range from Ghana cedi 200,000 to Ghana cedi 500,000 per acre. ${ }^{8}$

In addition to simply accessing sufficient capital, the ongoing management of capital is critical so that the demands of each new crop can be met. Producers reported obtaining the capital to initiate tomato production from family members, and using savings from other agricultural or trading activities. One woman said that she worked as a labourer and used the money to grow tomatoes while another used profits from a cassava crop. Although a number of cases were reported of loans being obtained from family members specifically for tomato production, there was considerable hesitancy to discuss these in any detail. In any case intra-family links and norms of reciprocity mean that the distinction between loans and gifts is often blurred. Apart from the FREQUE loans that were available to women in the late 1990s and made it possible for five Pamdu women to enter into production for the first time, one other woman reported borrowing money from the bank specifically to grow tomatoes. A small number of producers reported having bank accounts, but at the time these seemed to be used primarily for long-term savings to support special projects. ${ }^{9}$ Those who had invested in activities such as a kiosk or bulk grain trading, or had other sources of off-farm income, were able to shift funds among these activities and it has already been noted that men appeared to invest some of their off-farm income in farming.

For those producers who had no other major sources of income, it seemed that a significant element of capital management was to keep it in constant use. Indeed, this may have been one of the important roles of the dry season tomato crop: keeping capital out of circulation during this period helped preserve it for use during the next rainy season. As noted earlier, women were less 
likely to be involved in dry season production and their production patterns were more fragmented than those of men, which may have affected their ability to keep capital in use throughout the year.

\subsection{Food}

The household or domestic group provides the most immediate setting for young people's involvement in tomato production. Our argument is that the domestic arrangements that characterise these settings have a significant impact on the ability of individuals to engage in tomato production in a substantial way. Here we focus on food as a resource required for intensive tomato production, and how domestic arrangements impact on its availability. This section is based on a 1999 survey of cooking activities and food exchange involving 16 Akan households in Pamdu. ${ }^{10}$

We have already pointed to the fact that many women and most men (with the exception of young unmarried men) produce food crops, in part for local consumption. As is typical among the Akan, in Pamdu women did the bulk of the cooking. They cooked in their positions as spouses, 'mothers', grandmothers, 'sisters' and daughters, and in the process, prepared food for children, for young, unmarried men, for one another, and for brothers and husbands (with whom they may or may not be co-residing). ${ }^{11}$ In other words, cooking was not solely - or indeed primarily - about husbands, wives and 'household food security'. Further, not all women were directly involved in cooking food on a daily basis. This is not to say that cooking is not a time-consuming activity. Rather, the point is that food preparation and exchange (i.e. food allocation) are important elements of social life, both demonstrating and reinforcing complex webs of social relations. ${ }^{12}$

For example, in Pamdu access to food was not necessarily gained through marriage, or via membership of a specific household. Among kin, a common exchange was between sisters and siblings in general, although this did not exclude cooking for spouses resident in other houses. Thus for example, in a house occupied by two sisters, one of whom was married, cooked food was sent to the spouse and adult children living together in another house, and to a married senior sister who was co-residing with her husband. Similarly, in another house, a sister cooked for her unmarried younger brother who was sleeping alone in a newly constructed, tworoom building. Yet another woman who sometimes cooked for her non-resident younger sister, said cooking for sisters is done because 'this is how we show who we care for'.

Meanwhile, this same woman's husband was residing with matrikin at Bosom Krom $(1 \mathrm{~km}$ north of Pamdu) and he sometimes sent her money to buy food: other women also cooked and sent food to non-resident husbands co-residing with matrikin. Cooking for adult offspring may continue until they marry and food responsibilities for spouses are linked with responsibilities for offspring. Thus, the woman cited above sent food to her husband in Bosom Krom 'because his child is here'.

These arrangements and the resulting flows and exchanges of food, were critical for young tomato producers, who were frequently single men, since they allowed their attention to be focused entirely on the tomatoes, without the distraction of also having to produce food crops. In other words, the rapid accumulation of capital through intensive tomato production could only happen because these young men continued to be fed by their mothers, sisters or grandmothers until they married. Pamdu's dynamic and very profitable tomato economy, while powered by young men, was dependent to an important degree on the availability of women's domestic labour and surplus food crops. This picture is similar to that described by Guyer (1986) and others (e.g. Jackson 2003; Whitehead and Kabeer 2001) concerning the link between food grown for consumption and food grown for sale. While some young men in Pamdu contributed something towards the cost of foodstuffs, few acknowledged an obligation to provide staple foods such as yams. ${ }^{13}$ All this changed with marriage, after which the provision of food by these men became an important and acknowledged obligation.

While men aged 26-35 farmed a larger area of tomatoes than younger men, the percentage of total land farmed given over to maize and yam farming increased. The proportion of men producing tomatoes during the dry season also declined with increasing age. As noted by Whitehead (1998), both men and women respond to opportunities and obligations, but they do so from different starting points. Thus, 
unlike the case of women for whom the care of others (adults or their own children) starts very early and precedes marriage, it is marriage and the birth of offspring that change the context within which young men produce tomatoes and farm more generally.

For women, domestic responsibilities including childcare and cooking are just not compatible with the time and level of management required for tomato production, particularly during the dry season. It was also viewed as being very arduous work, and for one reason or another, the women did not turn to the option of working in groups as did their male counterparts, although they did share childcare with other family members, and benefited from some of the food exchanges already detailed. In terms of farming, they were more likely to be growing other vegetables, and in 2011 , these alternatives to tomato production were reported to have grown in importance, for both men and women, as the market for tomatoes had declined.

\section{Life and work: expectations and achievements}

In 2011 we tracked the cohort of people who had been engaged in tomato production in 1999. From our original list of 32 (20 men and 12 women), only one could not be traced in 2011. Four individuals, one woman and three men, had died, and the information in this section therefore refers to a sample of 27 (16 men and 11 women). Our main interest during the 2011 visit was to assess some of our earlier observations and hypotheses about the value of different crops through life, and the special interests of young rural men in agriculture.

We have already referred to tomato production, and especially intensive, high return dry season production as providing much needed capital for young people seeking to establish their independent lives. In 1999 we asked about their 'plans', and two interests stood out, building or extending a house and the establishment or expansion of trade or a small business. For young women, a plan involving trade or a small business referred almost entirely to trade in food crops or fish, to be sold in the main markets in the nearby towns of Techiman and Kintampo, or even in towns further north. Two others talked of building a kiosk and were planning to become, in one case, a hairdresser, and in the other a seamstress. At the time there were a number of kiosks in the town and hairdressing for women appeared to be a popular business choice (also see Langevang and Gough 2012). While a short cycle, high value crop might appear ideal for women, our conversations in Pamdu revealed that young women did not see their futures in terms of farming. In response to our question about her five-year plan, one female 3-cropper replied, 'To be in my kiosk and to have stopped farming'. Another woman pointed out that 'it is difficult to trade and farm' (with the implication that the former was more desirable than the latter). Based on the analysis presented earlier, this choice would not appear to be a question of lack of access to land. This choice was also not limited to women. Men also expressed interest in setting up a kiosk or store or learning a trade: in one house two brothers were planning to trade in sandals to earn enough money to travel.

Accumulating funds for travel was specific to the younger men and this included both travel to urban areas in Ghana as well as travel to international destinations. In 1999 we queried the practical reality of international travel and were told emphatically that it was possible if the money was available. As with the other plans like building a house or kiosk and investing in trading, there were a number of precedents in the village for international travel in search of work and adventure.

None of our informants indicated any plans to expand their dry season tomato production by investing in, for example, a small irrigation pump. Indeed, when we returned in 2011, the only person who appeared to have invested in additional pump capacity was an individual who already had a pump in 1999.

By 2011 we were able to see how some of the plans of these 27 individuals had materialised, and to learn more about their continuing relationship with agriculture.

Seven of these individuals (six men and one woman) were no longer living in Pamdu: six were living elsewhere in Ghana (in Kintampo, Techiman, Accra (2) and one 'somewhere in the Western Region'), while one man was in South Africa.

Of the ten women still resident in Pamdu (Table 2), three reported having achieved, or 
Table 22011 follow-up of women in Pamdu who were producing tomatoes in 1999

\begin{tabular}{|c|c|c|c|}
\hline Stated plans in 1999 & Plans achieved by $2011 ?$ & Engagement in farming in 2011 & Notes \\
\hline $\begin{array}{l}\text { Build house for children; } \\
\text { expand food trading (11) }\end{array}$ & $\begin{array}{l}\text { No, house not built; } \\
\text { not trading }\end{array}$ & $\begin{array}{l}\text { Tree crops only - teak and } \\
\text { cashew }\end{array}$ & $\begin{array}{l}\text { She has been sick for some } \\
\text { time. Now divorced. Has } \\
8 \text { children - one is a farmer }\end{array}$ \\
\hline Trade (18) & No, not trading & $\begin{array}{l}\text { No tomatoes; all usual food } \\
\text { crops } \\
\text { No trees }\end{array}$ & $\begin{array}{l}\text { She says she stopped growing } \\
\text { tomatoes } 4 \text { years ago because } \\
\text { she had no more strength. } \\
\text { Has } 8 \text { children - one is a } \\
\text { farmer. Husband farms }\end{array}$ \\
\hline Trade (28) & No, not trading & $\begin{array}{l}\text { Wet season tomatoes; maize } \\
\text { No trees }\end{array}$ & $\begin{array}{l}\text { Spouse died so never traded. } \\
\text { Farms using hired labour. Has } \\
3 \text { children and siblings and } \\
\text { parents in the village }\end{array}$ \\
\hline Build house (38) & No, house not built & $\begin{array}{l}\text { Wet season tomatoes and } \\
\text { other vegetables; maize and } \\
\text { yam } \\
\text { Tree crops - cashew and mango }\end{array}$ & $\begin{array}{l}\text { No house. Has } 6 \text { children - } \\
\text { all in school. Husband farms }\end{array}$ \\
\hline Expand trading (97) & Yes, expanded trading & $\begin{array}{l}\text { Wet season tomatoes; food } \\
\text { crops } \\
\text { Tree crops - cashew and mango }\end{array}$ & $\begin{array}{l}\text { Has } 5 \text { children, all schooled. } \\
\text { None farming. Senior son } \\
\text { went to Libya. Spouse lives in } \\
\text { Gabon }\end{array}$ \\
\hline $\begin{array}{l}\text { Expand house; educate } \\
\text { children (106) }\end{array}$ & $\begin{array}{l}\text { No, house not expanded } \\
\text { Yes, educated children }\end{array}$ & $\begin{array}{l}\text { No tomatoes; maize (rents land) } \\
\text { and other food crops } \\
\text { Tree crops - cashew and mango }\end{array}$ & $\begin{array}{l}\text { She also trades which she says } \\
\text { is more remunerative than } \\
\text { farming. Has } 4 \text { children - all } \\
\text { schooled. None farming. Now } \\
\text { divorced but husband } \\
\text { contributed to children's } \\
\text { education }\end{array}$ \\
\hline Refund FREQUE loan (114) & No, loan not repaid & $\begin{array}{l}\text { Wet season tomatoes; maize } \\
\text { and cassava } \\
\text { No trees }\end{array}$ & $\begin{array}{l}\text { She is a teacher in training. } \\
\text { Has } 4 \text { children. All schooled. } \\
\text { None in farming }\end{array}$ \\
\hline Build a house (143) & $\begin{array}{l}\text { House started in } 2009 \\
\text { and just completed by } \\
\text { husband }\end{array}$ & Tree crops only - cashew & $\begin{array}{l}\text { She fell sick soon after our } \\
\text { last visit } \\
\text { She does some small trading. } \\
\text { Has } 4 \text { children - one farming. } \\
\text { Husband farms and has } \\
\text { project animals - goats, } \\
\text { sheep, chickens }\end{array}$ \\
\hline $\begin{array}{l}\text { Build a kiosk; don't farm } \\
\text { (33) }\end{array}$ & No, kiosk not built & No information & $\begin{array}{l}\text { Neighbours reported that she } \\
\text { had travelled }\end{array}$ \\
\hline $\begin{array}{l}\text { Expand fish trading; build } \\
\text { a house (3) }\end{array}$ & $\begin{array}{l}\text { Yes, expanded trading } \\
\text { No, house not built }\end{array}$ & $\begin{array}{l}\text { None but plans to plant mango } \\
\text { and cashew trees. Purchased } \\
\text { (with spouse) } 8 \text { acres from the } \\
\text { chief } 2 \text { years ago }\end{array}$ & $\begin{array}{l}\text { She trades fish, mangoes and } \\
\text { tomatoes and will build a } \\
\text { kiosk from proceeds. She has } \\
4 \text { children - all schooled, } \\
\text { none farming. Husband lives } \\
\text { in USA and is sending money } \\
\text { to build a house in Pamdu }\end{array}$ \\
\hline
\end{tabular}

Note Numbers in parentheses refer to household ID. 


\begin{tabular}{|c|c|c|c|}
\hline Stated plans in 1999 & Plans achieved by $2011 ?$ & Engagement in farming in 2011 & Notes \\
\hline Travel to Libya (17) & No, did not travel & $\begin{array}{l}\text { No tomatoes. Cassava and } \\
\text { maize } \\
\text { Tree crops - cashew }\end{array}$ & $\begin{array}{l}\text { Stopped tomatoes this year } \\
\text { but will grow vegetables again }\end{array}$ \\
\hline Build a house (21) & No, house not built & $\begin{array}{l}\text { Dry season tomatoes; building } \\
\text { fish farm. No other crops yet } \\
\text { but has land } \\
\text { No tree crops }\end{array}$ & $\begin{array}{l}\text { Travelled to Ivory Coast and } \\
\text { just returned }\end{array}$ \\
\hline $\begin{array}{l}\text { Trade (shoes); become a } \\
\text { carpenter (24) }\end{array}$ & $\begin{array}{l}\text { Yes, started selling } \\
\text { shoes } \\
\text { No, did not become a } \\
\text { carpenter }\end{array}$ & $\begin{array}{l}\text { Dry and wet season tomatoes } \\
\text { and other vegetables } \\
\text { Will plant tree crops }\end{array}$ & $\begin{array}{l}\text { Started selling shoes and then } \\
\text { travelled to Libya. Father is } \\
\text { community chairman }\end{array}$ \\
\hline $\begin{array}{l}\text { Build a house; establish a } \\
\text { kiosk; become electrician } \\
\text { (50) }\end{array}$ & $\begin{array}{l}\text { Yes, built house and } \\
\text { kiosk } \\
\text { No electrician training }\end{array}$ & $\begin{array}{l}\text { Dry and wet season tomatoes; } \\
\text { food crops } \\
\text { Tree crops - cashew }\end{array}$ & $\begin{array}{l}\text { Father died so no funds for } \\
\text { electrician training. Farm } \\
\text { income provided capital for } \\
\text { house and kiosk }\end{array}$ \\
\hline Carpentry (103) & Yes, now a carpenter & $\begin{array}{l}\text { No information. Unable to } \\
\text { meet this man }\end{array}$ & \\
\hline $\begin{array}{l}\text { Build a house and marry } \\
(105)\end{array}$ & $\begin{array}{l}\text { Yes, married } \\
\text { No, house not built }\end{array}$ & $\begin{array}{l}\text { Wet season tomatoes; } \\
\text { food crops } \\
\text { Tree crops - mango and plans } \\
\text { for cashew }\end{array}$ & $\begin{array}{l}\text { Stopped dry season tomatoes } \\
2 \text { years ago. Lived many years } \\
\text { in Nigeria when he was } \\
\text { younger }\end{array}$ \\
\hline Carpentry (105) & Yes, now a carpenter & $\begin{array}{l}\text { Dry and wet season tomatoes } \\
\text { and food crops } \\
\text { No trees }\end{array}$ & $\begin{array}{l}\text { Carpentry better than farming } \\
\text { but does both }\end{array}$ \\
\hline $\begin{array}{l}\text { General provisions shop } \\
\text { (115) }\end{array}$ & Yes, has shop & $\begin{array}{l}\text { Moved from maize to trees - } \\
\text { mango and cashew }\end{array}$ & $\begin{array}{l}\text { Store built from farm income. } \\
\text { Income sources include the } \\
\text { provisions store, farming, and } \\
\text { electric meter reading. Wife is } \\
\text { a teacher }\end{array}$ \\
\hline $\begin{array}{l}\text { Build a house, move to } \\
\text { urban centre (119) }\end{array}$ & $\begin{array}{l}\text { Yes, built a } 6 \text {-bedroom } \\
\text { house; } 2 \text { bedrooms } \\
\text { yet to be completed }\end{array}$ & $\begin{array}{l}\text { Concentrates on cashew, } \\
\text { mango and citrus }\end{array}$ & $\begin{array}{l}\text { Major income sources include } \\
\text { teaching (he is head teacher) } \\
\text { and tree crops. Land sale } \\
\text { contributed to house-building }\end{array}$ \\
\hline $\begin{array}{l}\text { Drive and live in an urban } \\
\text { area (144) }\end{array}$ & $\begin{array}{l}\text { No, information on } \\
\text { driving } \\
\text { No, not working in an } \\
\text { urban area }\end{array}$ & Still farming but no details & \\
\hline
\end{tabular}

Note Numbers in parentheses refer to household ID.

partially achieved, the plans they articulated in 1999. For two of these women, their achievements were in their expanded trading activities, whereas the third (now divorced) had contributed, along with her spouse, to the education of their four children. None had been in a position to build or finish the construction of a house. Various reasons were given to explain what had happened, from the death of a husband who was to have provided the funds for trading, to the fact that they themselves had fallen sick. All the women at some point in our discussions pointed to the fact that they had managed to educate their children with a small number having entered secondary school, and some having completed or planning to complete tertiary education. 
Of the ten men still residing in Pamdu (Table 3), seven had achieved some or all of their objectives. Two of four who had planned to build a house had been especially successful. While one stated that he had completed his house and store using farm income, the second had sold land for his house-building project. However, both of these individuals had a number of income sources. It seems from these few cases that building sufficient capital in order to undertake a larger project such as house-building or establishing a business is challenging, and requires more than the quick money that can be accumulated from tomato production.

Only two of the 20 individuals - both women were not farming. All ten men were engaged to some degree in farming, even one who had managed to establish himself as a carpenter and had remarked that carpentry was more remunerative. Four men were still growing both wet and dry season tomatoes. Others were at least growing a maize crop, and possibly some other vegetables. Tree crops and specifically cashew were being talked about as the crops for the future. One woman noted that she and the husband had purchased land specifically for cashew planting since 'family land is common land' and the trees are 'for the children'.

Were there signs of anything policymakers might view as 'modern' or 'scientific' agriculture in Pamdu in 2011? In 1999 there were two small 'chemical' kiosks in Pamdu and we noted at the time the policy to implement stricter controls over the sale of chemicals from kiosks where bulk products were broken down into smaller quantities with little attention to safety. In 2011 there was only one, larger chemical store that appeared to be more secure, and included more expensive products, especially herbicides, but also fertiliser. Herbicides were talked about in 1999 but their use in 2011 was visible. We saw numerous tree crop plots (especially cashew but also mango) where herbicides had been used to clear around the base of the trunks. We also noted the use of herbicides on some vegetable plots. However, other than the use of pesticide and increased planting of cashew and mango, there were few other signs of an emerging agricultural revolution.

Yet, agriculture in Pamdu has changed between 1999 and 2011. The tomato market is less secure and the tomato growers association never meets. The tomato variety 'Power', which was dominant in 1999, was still being used, but there were also other varieties. Everyone mentioned a shift from tomatoes towards other vegetables, although there were still men engaged in producing tomatoes in the dry season, including three of our original cohort of young men. Nevertheless, dry season tomato production is still seen as a means of capital accumulation: as we walked along the river one day we were shown an area now referred to as 'Libya', 'because that is where people go to farm if they are planning to go to Libya' (an often referred to destination, both for work and as a transit point for Europe).

\section{Conclusions}

We started this article by suggesting there was tension between the ways that young rural women and men engage with and use agriculture to build their livelihoods, and the policies and programmes commonly relied upon to address the 'youth in agriculture' problem. We also suggested that research, policy and youth-related programmes must appreciate that rural young people - the youth - are actually highly differentiated, exercise choices about their lives and work, and rely on complex social networks to take the first crucial steps in livelihood building.

During our 1999 fieldwork in Pamdu most informants referred to both 'quick money' and 'Power': the former explained their interest in intensive tomato production, while the latter was the name of the most commonly grown tomato variety. Young people in Pamdu tried to use their tomato production to quickly accumulate a significant quantity of capital that they planned to use to further specific projects that would help them launch their independent lives. As such, they used tomato production in a very instrumental and short-term way: the 'quick money' that they could generate giving them some additional 'power' to shape the crucial first steps in livelihood building. Neither the sustainability of the tomato production system, nor their long-term engagement in agriculture was a key concern. Nevertheless, at least in this location where there is a wide variety of crop production possibilities, staying in the village means continuing some engagement with farming. However, in most cases farming is combined with other income-generating activities: there is little evidence in Pamdu of 
what might be considered full-time or 'career' farming. Further, by 2011 there were few if any signs of a technology-led 'Green Revolution'. This would suggest that the 'problem of rural youth' is not necessarily the appropriate starting point for the policies needed to develop and maintain a thriving agricultural economy.

The findings suggest that micro-studies can provide insight for policy formulation.

Specifically, our work in Pamdu points to the need to re-evaluate common understandings of how young people engage with and use agriculture: for example, avoiding the welltrodden path that sees young men as only being attracted to modern, larger-scale agriculture, and young women as constrained in their access to land. While there are opportunities outside agriculture, there are also a range of different patterns of farming that can be observed - from short-term involvement in small-scale, labour-

\section{Notes}

* This article draws on a research project entitled 'Policy Implications of Enterprise Agriculture as a Component of Rural Livelihood

Diversification in West Africa', undertaken in Ghana in 1998-9. The research was funded by the Department for International Development of the United Kingdom; however, the views expressed are those of the authors alone. We gratefully acknowledge the contribution of Kipo Jimah to the September 2011 restudy.

1 See Okali and Sumberg (1999) for more detail on the study site and research methods, and Sumberg and Okali (2006) for an analysis of tomato production in Pamdu and its links to and implications for environmental management.

2 In Pamdu, FREQUE is a group of 18 women and 2 men linked with a regional organisation with headquarters in Kintampo which receives financial support from a European, church-related organisation. One of those interviewed received a FREQUE loan but invested in maize and not tomatoes.

3 No men reported their tomato production in buckets.

4 Significantly, these same women also accessed funds for cashew planting and for maize storage from NGO development programmes in the village.

5 'Earthing-up' is the term used for the pulling of soil up around the lower part of the tomato intensive commercial farming or agri-business activities, to lifelong but fluid and shifting engagement with different crops and types of production (adding a new life-cycle dimension to the notion of 'shifting' cultivation). Policy must embrace and build upon these various patterns and scenarios, and to do this the very framing of the 'youth in agriculture problem' must change.

The challenges facing African smallholder agriculture cannot be laid at the feet of young people; nor should keeping 'the youth' on the land be a major objective of agricultural policy. The sooner that pundits, policymakers and development actors abandon the view that (valuable/vulnerable) young people and (threatened) society would both be better off if only the young people stayed on the farm - indeed, that they somehow 'owe it to the nation' to farm the sooner we will see the emergence of more reasoned policy and more relevant programmes.

stem, thus forming a substantial ridge along the row of plants.

6 The term nnoboa refers to labour exchange groups. This term was used exclusively to refer to labour groups formed of young men. There was only one case reported of older men forming a group for other crops. A few women reported working as a group for threshing maize.

7 In January 1999, £1 = Ghana cedi 4,000; US $\$ 1=$ Ghana cedi 2,300 .

8 These figures take no account of the producer's living costs during the period of production.

9 One individual reported saving the profits from the sale of over 100 crates of tomatoes in the Commercial Bank - he needed Ghana cedi 7 million to join his 'brother' in London, while another claimed to have Ghana cedi 400,000 in the bank which he would eventually use to establish himself as a sandal trader.

10 In considering the channels through which access to food is gained, it is important to remember that agriculturally, Pamdu is relatively rich and productive, and overall, food does not appear to be in short supply.

$11 \mathrm{It}$ is important to note that those on the receiving end of these exchanges are not necessarily lacking food, indeed one senior man regularly received food from a number of different women. This individual lived alone and received much more food that he could 
consume. In cases such as this his role was reported to be to taste the food and then to re-distribute it to others for consumption.

12 Also see Clark (1994), who in her study of Kumasi market women emphasises the significance of women cooking for men in recognition of claims to, for example, support for children.

13 Although the areas covered by Whitehead (1998: 24) did not include the kind of

\section{References}

Amanor, K. (2010) 'Family Values, Land Sales and Agricultural Commodification in Southeastern Ghana', Africa 80.1: 104-25

Anyidoho, N.A.; Kayuni, H.; Ndungu, J.; Leavy, J.; Sall, M.; Tadele, G. and Sumberg, J. (2012) Young People and Policy Narratives in Sub-Saharan Africa, Future Agricultures Consortium Working Paper 032, Brighton: FAC

Benin, S.; Johnson, M.; Jimah, K.; Taabazuing, J.; Tenga, A.; Abokyi, E.; Nasser, G.; Ahorbo, G. and Owusu, V. (2012) 'Evaluation of Four Special Initiatives of the Ministry of Food and Agriculture, Government of Ghana' unpublished Draft Report, 8 November 2011

Berry, S. (2009) 'Building for the Future? Investment, Land Reform and the Contingency of Ownership in Contemporary Ghana', World Development 37.8: 1370-8

Clark, G. (1994) Onions are my Husband. Survival and Accumulation by West African Market Women, Chicago: University of Chicago Press

Guyer, Jane I. (1986) 'Intra-Household Processes and Farming Systems Research: Perspectives from Anthropology', in J.L. Moock (ed.), Understanding Africa's Rural Households and Farming Systems, Boulder CO and London: Westview Press: 92-104

Jackson, C. (2003) 'Gender Analysis of Land: Beyond Land Rights for Women?', Journal of Agrarian Change 3.4: 453-80

Langevang, T. and Gough, K.V. (2012) 'Diverging Pathways: Young Female Employment and Entrepreneurship in Sub-Saharan Africa', Geographical Journal 178.3: 242-52 intensive cash crop production observed in Pamdu, she argues that 'the self provisioning element of smallholder production is still a highly significant proportion of the farming enterprise and staple foods occupy a particular place in the farming and household allocation system. They are not treated as income but as consumption goods and access to them is not based on ideas of direct exchange for labour input'.

Okali, C. (2012) Gender Analysis: Engaging with Rural Development and Agricultural Policy Processes, Future Agricultures Consortium Working Paper 026, Brighton: FAC

Okali, C. (1983) Cocoa and Kinship in Ghana: The Matrilineal Akan of Ghana, London: Kegan Paul International

Okali, C. and Sumberg, J. (1999) Policy Implications of Enterprise Agriculture as a Component of Rural Livelihood Diversification in West Africa (ESCOR Grant No. R6780), Final Report, Norwich: Overseas Development Group, School of Development Studies, University of East Anglia

Spiro, H. (1985) The Ilora Farm Settlement in Nigeria, Women's Roles and Gender Differences in Development, Cases for Planners 5 (series), West Hartford: Kumarian Press

Sumberg, J. and Okali, C. (2006) 'Tomatoes, Decentralization, and Environmental Management in Brong Ahafo, Ghana', Society and Natural Resources 19.1: 19-31

Whitehead, A. (1998) 'Gender, Poverty and IntraHousehold Relations in Sub-Saharan African Small Holder Households: Some Lessons from Two Case Examples', background paper prepared for the 1998 SPA Report on Poverty and Gender in Sub-Saharan Africa, Washington DC: World Bank

Whitehead, A. and Kabeer, N. (2001) Living with Uncertainty: Gender, Livelihoods and Pro-Poor Growth in Rural Sub-Saharan Africa, Working Paper 134, Brighton: IDS 